\section{The Characteristics of the Traditional Chinese Theather Jing} $\mathrm{Ju}$

\author{
Tri Utari Ismayuni ${ }^{1}$, Nanda Saputra ${ }^{2}$ \\ 1,2STIM Sukma Medan, STIT Al-Hilal Sigli, Indonesia \\ Email: tariismayunii@gmail.com, nandasaputra680@gmail.com
}

\begin{abstract}
:
The title of the paper is "Characters in Jing Ju Traditional Chinese Theatre". In This paper, the writer wants to analyze the characters from Jing Ju Traditional theatre. This paper talks about the method of the analysis which is used by the writer is descriptive comparative method. And the theory which is used in comparing and analyzed the characters and the meanings of the analysis, the writer show and describes the character which exists in Jing Ju theatre, the meaning of the mask colors from each theatre.
\end{abstract}

Keywords:

traditional; theatre; chinese

\section{Introduction}

China is one of the countries in the world that is rich in cultural arts. One of the Chinese cultural arts is performing arts. The performing arts in China has no less than 300 types of local traditional theaters throughout China, including the most popular theater throughout the world, namely the traditional Chinese theater called Jing Ju (Ayu Ria Syrfiani. 2011: 35). Tradition is something that is passed down from the heritage of the ancestors to the next generation in a relay descends performed by the indigenous communities that have become deeply entrenched the culture in life. Customs and traditions include the creation and work of human beings who have become convictions in regulating the social order of life. (Pane et al, 2020).

The origins of traditional Chinese theater Jing Ju were born at the end of the 18th century, when the Huiban or Anhui provincial theater group joined a local theater group from Huibei and came to Bejing for a performance celebrating the birthday of the Qianlong emperor of the Qing Dynasty around 1790 (Chunjiang Fu, 2011: 21). The merging of these two local theaters then resulted in a new theatrical performance that was more varied and entertaining, thus becoming a theater that was in demand by the public at that time. This amalgamation of theaters became the basic principles of Jing Ju traditional theatre.

The two local theaters then developed. Their performances also absorb a lot of plays and methods from local theater groups that come to Beijing. Therefore, after years of assimilation and becoming the largest theater in China, this theater became known as the Beijing theater (Jing Ju). Jing means the capital of a country, also taken from the word Beijing, the capital of China at that time. Ju means performance, drama, theater (play). Jing Ju traditional Chinese theater has its own uniqueness compared to other theaters, because Jing Ju traditional Chinese theater is a blend of vocal arts, dialogue, acting, acrobatics, and dance. Jing Ju traditional Chinese theater also has its own rules in how to tell stories, depict characters, arrange costumes from headdresses, clothes, shoes, etc. 


\section{Lakhomi Journal: Scientific Journal of Culture \\ ISSN: 2774-311X (Online), 2774-4728 (Print)}

Vol. 2, No. 2, June 2021, Page: 65-72

Email: lakhomijournal@gmail.com

In the traditional Chinese theater Jing Ju there are four characters that are contained in it in general, namely:

1. Shng (Men)

2. And (woman)

3. Jing (painted face man)

4. Chou (man comedian)

Many folk tales are often staged in traditional Chinese theatrical performances of Jing Ju . in each story contains a variety of values of life, social and education which are very interesting to see, one of the interesting stories is "The Sword of Cosmos" the story contains many values of loyalty, social values in life and obedience, the story has a royal background in the show.

Jing Ju traditional Chinese theater has a story that is rich in life, social, and educational values that can make a very interesting show and is rich in traditional culture in its performances, Jing Ju traditional Chinese theater is a very famous theater in China and is a traditional theater that the largest in the country. The author hopes that this article can be one of the readings as an addition to new knowledge, and the author can introduce traditional Chinese Jing Ju theater which is very rarely found, even though there is no place for learning traditional Chinese theater Jing Ju in North Sumatra, but from this article it is hoped that can be new knowledge and learning in the introduction of traditional Chinese theater Jing Ju. In this paper, the author only focuses on the characters of the traditional Chinese theater Jing Ju, where this traditional theater is very rich in life, social, cultural and educational values. This traditional theater has a royal background story. The author will discuss one by one the characters contained in each character. Each character from the traditional theater has its own uniqueness in each character. That's what makes the author interested in discussing it. Each character from the traditional theater has its own uniqueness in each character. That's what makes the author interested in discussing it. Each character from the traditional theater has its own uniqueness in each character. That's what makes the author interested in discussing it.

\section{Research Methods}

Etymologically the word methodology comes from the Greek Mhethodos and Logos. Methodos means way or way, Logos means knowledge. So, the methodology or method is a way related to how to work in achieving the desired goal or goal in solving a problem. Methodology is "something that uses the mind carefully to achieve a goal" (Narbuko, 1997: 1). Meanwhile, according to Sudaryanto (1988: 26-17) the method is "the method used in obtaining data from collection to broadcasting of the results of this data analysis".

In this writing, the writer uses the library method. This method is carried out to obtain information relevant to the topic or problem being studied. This information can be obtained from reading books, scientific essays, theses, journals, and written sources both in print and other electronic forms. The interview method is conducting interviews with informants who are considered to meet the requirements as informants to be able to collect the required data. In conducting interviews the author also uses interview guidelines that have been prepared in advance by the author so that the interview does not deviate from the object under study, after that the author provides a series of questions about the language to be asked, 


\section{Results and Discussion}

\subsection{Figures and Characters in Traditional Chinese Theater (Jing Ju)}

Traditional Chinese theater (Jing ju) has 4 main categories of roles, namely the main male role (Sheng), the female lead role (Dan), the male supporting role (Jing), and the role of a clown or comedian (Chou).

1. Laosheng: Having the character of a grown man or an old man, the personality of this character is usually honest, generous, but tough. In semoiotic theory, it can be seen in the Rhematic symbol or symbolic theme that Laosheng figures wear a fake beard (or mustache) usually Laosheng plays the role of emperor, court official, scholar or advisor and usually only sings and acts a little, there are several types of fake beards divided into black which indicates that the role of Laosheng who uses a black beard indicates that the role is a middle-aged man, the gray beard indicates that the role of Laosheng has a male character whose age is between Laosheng's role who uses a black and white beard, while the role of Laosheng who wears a white beard has character with old age,

2. Xiao Sheng: is the role of a young man, usually good-looking, and not wearing a fake beard. xiaosheng usually plays a refined and educated official, while the role of xiaosheng who holds a fan and dresses as a student is usually romantic and carefree with a gentle and refined personality, the xiaosheng who has the feathers of a pheasant is a young official who wears a pheasant decoration this character masters literature and In martial arts, there is also a xiaosheng character as a poor scholar and usually wears a rectangular headgear and noble costume with patchwork.

3. Wu Sheng: is a military male character who masters martial arts and deals with fighting. In the theory of semiotic rhematic symbols, there are wusheng characters who are short armed, usually do not wear armor, only wear short weapons and their movements are agile. The Wu Sheng character acts as a soldier and long-armed wusheng wears clothing. This character usually acts as a military general, the character of the military general wears four triangular flags made of embroidery. The origin of the triangular flag made of embroidery is believed to be related to military officials who would send command flags to command their troops in ancient times. This embroidered flag is a large version of the commando flag. This flag is used as a decoration and can add to the character's charisma.

4. Qing Yi: is a simple, virtuous, elegant and calm young or middle-aged female character who plays the role of a good wife and loving mother or a pure and morally honest girl. In the semiotic theory of rhematic symbols, the Qing Yi character usually wears a silver or coppercoated headdress that reflects the woman's character from a poor or widowed family. Other Qing Yi characters play noble girls and women, daughters of kings or female emperors who wear kingfisher feathers, for clothing, Qing Yi's characters who play nobles wear ceremonial robes that are often used for the role of female emperors, rich women with backgrounds nobility.

5. Hua Dan: is a female character who is flirtatious, lively, has a brave personality, is full of enthusiasm and is usually funny and entertaining. The roles that are often played are maids, country girls, girls from simple families.

6. Huashan: is a character who has a combination of artistic characteristics of several female characters and characters who are proficient in singing, dialogue, acting and acrobatics.

7. Lao Dan: is the character of a wise old woman, in the semiotic theory of rhematic symbols, there is also the role of laodan as a funny and cunning character, it can be seen in her excessive appearance and make-up and is also known as the ugly Dan character or the ugly woman.

8. Jingmain: often called a big painted face, in the semiotic theory of Dicent symbol this character is focused on singing because in traditional Chinese theater performances Jing Ju 
the character is mostly singing (Fu Chunjiang 2011: 72) while in the semiotic rhematic symbol theory the role of Jing is the main have a painted face therefore this role is often called a singing painted face.

9. Jing second: is a Jing character known for his painted face or painted face pose ( $\mathrm{Fu}$ Chunjiang 2011 : 72 ). This character's focus is on movement and usually appears as a straightforward character. The second Jing also plays a cunning palace official who is whitefaced and also falls into this category of characters.

10.Chou: which has an ugly or funny character. For facial makeup, Chou's role is to form facial makeup such as white tofu that is drawn between the eyes and nose, and this character is also called a small painted face. The role of Chou is a comedian or gentle clown character. This character usually has no martial arts knowledge and plays various funny characters with various statuses and ages. Such as emperors, nobility, court officials, dandy, or people of low status.

\subsection{The Meaning of 'Traditional Chinese Theatrical Masks (Jing Ju)}

1. Red: The meaning of the red color contained in the traditional Chinese theater mask Jing Ju. The red color indicates or symbolizes that the character has the character of loyalty, courage, generosity, and generosity. In addition, the red color also implies that the character has great power.

2. White color: In traditional Chinese theater masks Jing Ju, the color white is generally used to describe characters who are cunning, immoral, treacherous, and full of deceit.

3. Black: In traditional Chinese theater masks, the black Jing Ju depicts positive values such as courage, loyalty, high integrity, honesty, and candor that the character has.

4. Blue: This blue color reflects a good character as well as a bad character, namely a character who has the character of great courage, firm stance, valor and full of resolution but on the other hand also has a savage and fierce nature.

5. Yellow: in traditional Chinese theater depicts the aggressive and brutal character of the character.

6. Gold and Silver Color: In traditional Chinese theater Jing Ju gold and silver colors depict figures such as gods, demons, mortals who have supernatural powers, spirits, imaginary characters in legends and especially for Shakyamuni Buddha. These gold and silver colors give the effect of majesty,

7. Green color: In traditional Chinese theater, a character who wears a green mask depicts a character who is passionate, angry, impatient, emotionally unstable or explosive, but also a brave or strong knight. 
3.3 Analysis of Characters in Traditional Chinese Jing ju Theatre

\begin{tabular}{|c|c|c|c|}
\hline $\begin{array}{l}\mathrm{N} \\
\mathrm{O}\end{array}$ & $\begin{array}{r}\text { Trac } \\
\mathrm{Cl}\end{array}$ & $\begin{array}{l}\text { ional Theater } \\
\text { nese Jing Ju }\end{array}$ & Character description \\
\hline & Character Name & Character image & Jing Ju Tradisional Traditional Chinese Theater \\
\hline 1. & Lao Sheng & & $\begin{array}{l}\text { The Laosheng character in the traditional } \\
\text { Chinese theater Jing Ju is a mature male character } \\
\text { or an old man, the personality of this character is } \\
\text { usually honest, generous but tough (the } \\
\text { protagonist) }\end{array}$ \\
\hline 2. & Xiao Sheng & & $\begin{array}{l}\text { The character of Xiao Sheng in the traditional } \\
\text { Chinese theater Jing Ju usually plays a young } \\
\text { man, who is attractive and kind and is also heroic } \\
\text { (protagonist). }\end{array}$ \\
\hline 3. & Lao Dan & & $\begin{array}{l}\text { The character of Lao Dan in the traditional } \\
\text { Chinese theater Jing Ju, has the character of a } \\
\text { wise old woman (the protagonist). }\end{array}$ \\
\hline 4. & Qing $Y i$ & & $\begin{array}{l}\text { The Qing Yi character found in the traditional } \\
\text { Chinese theater Jing Ju has a character, a young } \\
\text { or middle-aged woman who is simple, virtuous, } \\
\text { elegant and calm acting as a good wife and loving } \\
\text { mother or a pure and morally honest girl } \\
\text { (protagonist). }\end{array}$ \\
\hline
\end{tabular}




\begin{tabular}{|c|c|c|}
\hline 5. & Chou & $\begin{array}{l}\text { The chou character found in the traditional } \\
\text { Chinese theater Jing Ju, has a humorous or funny } \\
\text { character. This character is a supporting role } \\
\text { (tritagonist). }\end{array}$ \\
\hline 6. & $\begin{array}{l}\text { mask with } \\
\text { Red }\end{array}$ & $\begin{array}{l}\text { The red masks that are found in the traditional } \\
\text { Chinese theater Jing Ju, signify the characters of } \\
\text { loyalty, courage, generosity, and generosity. Has a } \\
\text { positive meaning in accordance with the } \\
\text { symbolic meaning of red in Chinese society } \\
\text { which has a symbolic meaning as the color of } \\
\text { religious rituals with the aim of bringing good } \\
\text { luck. }\end{array}$ \\
\hline 7. & $\begin{array}{l}\text { mask with } \\
\text { black }\end{array}$ & $\begin{array}{l}\text { In Chinese society, black is a neutral color that } \\
\text { has no negative meaning. Therefore, in } \\
\text { traditional Chinese theater masks Jing Ju which } \\
\text { has a black mask depicts positive values such as } \\
\text { courage, loyalty, high integrity, honesty, and } \\
\text { directness (having a positive meaning). }\end{array}$ \\
\hline 8. & $\begin{array}{l}\text { Mask } \\
\text { yellow }\end{array}$ & $\begin{array}{l}\text { In Chinese society, the color yellow is interpreted } \\
\text { as the color of mourning, because at the death } \\
\text { ceremony, Chinese people who adhere to } \\
\text { Buddhism use yellow in their mourning } \\
\text { ceremonial clothes. In traditional Chinese theater } \\
\text { Jing Ju, the yellow mask means bravery, } \\
\text { persistence, a clever thinker, good at hiding his } \\
\text { feelings, but on the other hand it also depicts an } \\
\text { aggressive and brutal character (has a negative } \\
\text { meaning). }\end{array}$ \\
\hline
\end{tabular}

Figure 1. Table of Character Analysis in Traditional Chinese Traditional Theater Jing ju 


\section{Conclusion}

After describing the characters in traditional Chinese theater Jing ju, it can be concluded.

1. The characters found in the traditional Chinese theater Jing Ju are:

The characters in the traditional Chinese theater Jing Ju are: Sheng as the main male role who has the character of a protagonist, And as the main female role who has the character of a protagonist, Jing as a supporting role whose face is painted has a tritagonist character depending on the color of the mask he uses and Chou as a comedian role that is tritagonist.

2. Mask characters found in traditional Chinese theater Jing Ju are:

The mask characters found in the traditional Chinese theater Jing Ju are: the color red which has the characters of loyalty, courage, generosity, and generosity, which is also contained in the meaning of the color red in Chinese society which has a sacred meaning as a color that brings luck in red. It is also often used on Chinese community celebration days. The color white has a cunning, immoral, traitorous, and deceitful character. This is also stated in the meaning of the color white for the Chinese community, the black color has the character of courage, loyalty, high integrity, honesty, and candor, the blue color has the character of courage that is strong. big, determined, valiant and full of resolution but also fierce and fierce, the color yellow has the character of valor, tenacity, a thinker who is clever at hiding his feelings but also describes an aggressive and brutal character, the colors gold and silver have the character of majesty, supernatural and supernatural powers, the color green has a character that is passionate, angry, impatient, emotionally unstable or explosive but is a valiant or stout knight.

\section{References}

Buchari, Muchtar. (1982). Manusia dan Kebudayaan.No.6.ke-II. Jakarta : PT Prisma.

Chunjiang, Fu. (2011). Origins of Chinese Opera. Jakarta: PT Elex Media Komputindo.

Depdikbud. (2005). Kamus Besar Bahasa Indonesia. Jakarta : Balai Pustaka

Endraswara, Suwardi. 2003. Metodologi Penelitian Kebudayaan. Yogyakarta: Gadjah Mada University Press.

Erlina. (2011). Metodologi Penelitian. Medan: USU Press.

Galery, Panda. (2008). Opera Beijing. http://id.wikipedia.org/wiki/Opera_Beijing

Hadari, Nawawi. (1994). Metode Penelitian Ilmiah. Jakarta : Rineka Cipta.

Haliday, M.A.K. (1992). Bahasa, Konteks, Dan Teks. Yogyakarta : Universitas Gadjah Mada.

Masinambow. (1997). Koentjaraningrat dan Antropologi di Indonesia. Jakarta: Yayasan Obor Indonesia.

Moedjono. (2011). Ragam Hias Dan Warna Sebagai Simbol Dalam Arsitektur Cina. Semarang : Jurnal

Mulyana, Deddy. (2008). Ilmu Komunikasi. Bandung : PT Remaja Rosdakarya Offset

Narbuko, Cholid. (1997). Metodologi Penelitian. Jakarta : Gramedia.

Nazir, Muhammad. (1986). Metode Penelitian. Bandung : Remaja Rosdakarya.

Pane, A., et al. (2020). The Performance of Mangupa Tradition in Angkola Custom, Medan, Indonesia. Budapest International Research and Critics Institute-Journal (BIRCIJournal). P. 1747-1757

Purihati, Nazli. (2010). Keistimewaan Peran Jing dalam Opera Beijing. http:lontar.ui.ac.id/opac/themes/libri2/detail.jps?id=20159676\&lokasi=lokal

Riantarno, Nano. (2011). Kitab Teater. Tanya Jawab Seputar Seni Pertunjukkan. Jakarta : PT Gramedia Widiasarana Indonesia.

Rida, Zeniar dan Cory Iriani. (1986). Materi Pokok Sejarah Kebudayaan. Jakarta : Universitas terbuka, Depdikbud. 
Seto, Indiawan. (2011).Semiotika Komunikasi. Jakarta : Mitra Wacana Media.

Sirviany P.S, Ayu Ria. (2011). Analisis Perwatakan Jing 净 : Berdasarkan Warna Dalam Tata Rias. Jakarta : Skripsi

Siti Zainon Ismail. (2002). Getaran, Jalur dan Warna. Petaling Jaya: Penerbit Fajar Bakti.

Zhao, Menglin \& Yang Jiqing. (1996). Pecking Opera Painted Faces. Beijing : Morning Glory Publishers

莫丽去. (2011). 《京剧》. 北京：时代出版转媒股份有限公司

管善群, 《店声技术基础》, 北京 : 北京师范大学出版社, 1998.7

曹揆申等《教育电声系统》, 北京: 高等教育出版社, 1996.12 